\title{
István Lengvári
}

\section{The Social Composition of Medical Students at the Erzsébet University Between 1930 and 1945}

\begin{abstract}
The purpose of the study. To examine the social composition of medical students of the Erzsébet University of Pécs (ETE) between 1930 and 1945 based on statistics about religion, place of birth and father/guardian occupation. To present the external processes affecting the admission of students based on the minutes of the university governing body. To present some typical individual careers of students of the examined period.

Applied methods. Statistical analysis of student enrolment and diploma books. Analysis of major processes using the minutes of the medical faculty and university council meetings and literature. Presenting and categorising careers using all available archival and library data.

Outcomes. Compared to the previous decade and a half, the number of medical students at ETE decreased for demographic and political reasons. The religious composition of the students changed due to measures restricting Jewish students' university admission, and disenfranchising them. The careers examined also demonstrate how affected students tried to circumvent these measures.
\end{abstract}

Keywords: social history, mobility, Pécs, university, numerus clausus, medical students, careers

\section{The situation of the university in Pécs during the period examined}

In the second part of our study, we continue the presentation of the period between the two world wars by examining the medical students of the 15-year period between 1930 and 1945 . By 1930, the university and, within it, the medical faculty, had become a key player in the life of the city of Pécs, and so did the clinics operating as the largest health care provider in the city and the region. By the 1930s, the faculty had become an increasingly important factor in Hungarian scientific life as well, and doctors graduating from Pécs appeared in clinics and settlements in the region. At the same time, however, plans to close the university emerged several times, which were avoided with significant lobbying and support from the city. The relocation of the Faculty of Humanities to Szeged in 1940 was a heavy loss for the university in Pécs as a whole. By the end of the decade examined, students graduating from Pécs had already appeared in institutes and clinics, and despite the economic difficulties, the number of units at the Faculty of Medicine had also increased. ${ }^{1}$

During the period examined, universities could not escape the effects of the Great Depression in Hungary and the consequences of World War II. With regards to the enrolment numbers, the anti-Jewish legislation Act XV of 1938, Act IV of 1939 and Act XV of 1941 further reduced the proportion of Jews in higher education. ${ }^{2}$

Our study is a continuation of our previous work ${ }^{3}$ presenting the first decade or so of the faculty's student body, where the reader will also find a description of the archival sources used. ${ }^{4}$

\footnotetext{
1 A more detailed overview is unnecessary due to a number of prior works on the subject listed here: Lengvári, I. (2021a): 72. Note 1.

2 For all anti-Jewish legislation see Karsai, L. (2005).

3 Lengvári, I. (2021a).

4 Pécsi Tudományegyetem (Pécs University, hereinafter PTE) Egyetemi Levéltár (University Archive, hereinafter EL), VIII.105.d. Erzsébet Tudományegyetem (Erzsébet University, hereinafter ETE), Orvostudományi Kar (Medical Faculty, hereinafter OtK), Iratkozási lapok, diplomakönyvek. (Enrolment forms, diploma books).
} 
In our current study, we examine students who acquired medical degrees from 1930/1931 to the end of the 1944/1945 academic year and includes only graduates of medical degrees, i.e., those who have not completed their studies or who have only completed a few semesters at the faculty are excluded, similar to our first paper.

\section{Number of students, ratio of men to women}

From the beginnings in Pozsony to the 1944/1945 academic year, there were 2,267 graduates, of whom 419 were women. The distribution by academic year is shown in the following table:

Table 1: Number of students based on diplomas awarded

\begin{tabular}{|c|c|c|c|}
\hline Academic year & $\begin{array}{c}\text { Number of } \\
\text { students, total }\end{array}$ & Women & $\%$ \\
\hline 1918-19 & 14 & 2 & 14.3 \\
\hline $1919-20$ & 4 & 0 & 0 \\
\hline 1920-21 & 12 & 0 & 0 \\
\hline $1921-22$ & 75 & 14 & 18.7 \\
\hline $1922-23$ & 104 & 13 & 12.5 \\
\hline 1923-24 & 169 & 34 & 20.1 \\
\hline 1924-25 & 122 & 32 & 26.2 \\
\hline $1925-26$ & 120 & 24 & 20.0 \\
\hline $1926-27$ & 209 & 68 & 32.5 \\
\hline $1927-28$ & 148 & 49 & 33.1 \\
\hline $1928-29$ & 111 & 22 & 19.8 \\
\hline 1929-30 & 109 & 25 & 22.9 \\
\hline 1930-31 & 68 & 12 & 17.6 \\
\hline 1931-32 & 80 & 9 & 11.3 \\
\hline 1932-33 & 60 & 5 & 8.3 \\
\hline 1933-34 & 55 & 6 & 10.9 \\
\hline 1934-35 & 71 & 8 & 11.27 \\
\hline $1935-36$ & 89 & 9 & 10.1 \\
\hline $1936-37$ & 57 & 7 & 12.3 \\
\hline $1937-38$ & 74 & 10 & 13.5 \\
\hline 1938-39 & 88 & 10 & 11.4 \\
\hline $1939-40$ & 72 & 10 & 13.9 \\
\hline $1940-41$ & 52 & 10 & 19.2 \\
\hline $1941-42$ & 52 & 8 & 15.4 \\
\hline $1942-43$ & 55 & 6 & 10.9 \\
\hline $1943-44$ & 48 & 7 & 14.6 \\
\hline $1944-45$ & 149 & 19 & 12.8 \\
\hline Total & 2,267 & 419 & 18.5 \\
\hline
\end{tabular}

The reason for the noticeable decline by the end of the 1920s (which occurred not only at the medical faculties) was that the government was trying to reduce the number of admissible students. The number of students receiving a degree remained low throughout the period in 
question, falling to around 50 in some years. The reason for the outstanding number in the last year of the examined period is that diplomas were issued early where possible in view of the WW II state of emergency.

\section{Religious composition}

Based on the data taken from the diploma books and the enrolment forms, the religious distribution in the examined period shows the following figures (data of the previous period are shown in parentheses):

Table 2: Religious distribution of medical graduates from the $1930 / 1931$ to the end of the 1944/1945 academic year

\begin{tabular}{|l|l|l|}
\hline Religion & Number of students & \% \\
\hline Roman Catholic & $(222) 566$ & $(18.56) 52.88$ \\
\hline Greek Orthodox & $(4) 15$ & $(0.33) 1.40$ \\
\hline Greek Catholic & $(0) 3$ & $(0) 0.28$ \\
\hline Lutheran & $(26) 72$ & $(2.17) 6.72$ \\
\hline Calvinist & $(58) 110$ & $(4.85) 10.27$ \\
\hline Unitarian & $(3) 2$ & $(0.25) 0.19$ \\
\hline Israelite & $(775) 204$ & $(64.80) 19.05$ \\
\hline N/A & $(108) 99$ & $(9.03) 9.24$ \\
\hline Total & $(\mathbf{1 1 9 6}) 1071$ & $(\mathbf{1 0 0}) 100$ \\
\hline
\end{tabular}

It is clear from the table that the number of Jewish graduates shows a significant decline, and as such only represent $20 \%$ of the total number of graduates. The continuous decline can be attributed to numerus clausus at first and later to the anti-Jewish laws. Representatives of the other major denominations, however, show two to three times the increase compared to the previous decade.

\section{Distribution by place of birth}

In the period examined, the distribution of 1,071 graduates by place of birth can be considered even, but the number of students from South Transdanubia is increasing. Based on the 1067 completed data, Baranya County contributed 136 (12.75\%), Somogy 73 (6.87\%) and Tolna 68 (6.37\%) people based on place of birth. The county seat Pécs contributed 69 graduates, which is a significant increase compared to the previous period. Among the counties of Transdanubia, Vas is represented by 50 (4.69\%), Zala 43 (4.03\%), and Veszprém by 20 (1.87\%) students: increasing numbers can be observed here as well compared to the previous period. Pest-PilisSolt-Kiskun County also stands out due to its size, although its percentage is decreasing: 66 (6.19\%) graduates came from here, not counting Budapest. (It is worth noting that Ujpest was not part of the capital yet). Most students came from Budapest (147 people, $13.78 \%$, a significant decrease from $25.83 \%$ in the previous period). The place of residence of the parent caregiver at the time of enrolment is also available in the enrolment forms, but this was completed for only a subset of students, 845 (100\%). Based on this, we know of 104 students (12.31\%) whose father/ guardian lived in Budapest during their university studies. (This percentage was $38.81 \%$ in the previous decade.) Between 1920 and 1930, Budapest made up 15-16\% of Hungary's population, so the previous over-representation of students from Budapest ceased. Returning to the birth data series, the religious distribution of the 147 graduates from Budapest is as follows (data from the previous period are shown in parentheses): 
Table 3: Religious distribution of medical graduates born in Budapest

from the 1930/1931 to the end of the 1944/1945 academic year

\begin{tabular}{|l|l|l|}
\hline Religion & Number of students & \% \\
\hline Roman Catholic & $(43) 61$ & $(13.92) 41.50$ \\
\hline Lutheran & $(6) 12$ & $(1.94) 8.16$ \\
\hline Calvinist & $(12) 10$ & $(3.88) 6.80$ \\
\hline Israelite & $(227) 45$ & $(73.46) 30.61$ \\
\hline Greek Orthodox & $(0) 1$ & $(0) 0.68$ \\
\hline Greek Catholic & $(0) 1$ & $(0) 0.68$ \\
\hline N/A & $(21) 13$ & $(6.80) 8.84$ \\
\hline Total & $(309) 147$ & $(100) 100$ \\
\hline
\end{tabular}

In the 1920s, Jewish students tried to gain admission or transfer to rural institutions from Budapest universities, because the Budapest institutions adhered more strictly to the provisions of numerus clausus. By the end of the 1920s, however, the universities in Budapest (not only the medical faculties) taught almost half of the Jewish student body, while the proportion of Christian students in the countryside (as seen in among the medical students of the Pécs medical faculty) increased. ${ }^{5}$

\section{Social background}

Unfortunately, the occupation of the father (guardian) was not provided in all cases, and this field can only be found in the enrolment forms. The data of a total of 940 students are available, representing $87.77 \%$ of the students examined. As in almost all periods and types of schools, we can state that the completion of this field is the most irregular, the most inaccurate - as the data were recorded on the basis of what information the students provided either orally, or in writing in the forms. The sometimes arbitrary categorisation by researchers, for example, obscures the problem that there can be huge differences in income and wealth behind an occupational classification. Our classification below is primarily based on the occupational structure: 6

Table 4: Occupation of father/guardian Budapest from 1930/1931 to the end of the 1944/1945 academic year (only taking into account the completed data sets)

\begin{tabular}{|l|l|l|}
\hline Father/guardian's occupation & $\begin{array}{l}\text { Number } \\
\text { students }\end{array}$ & of \\
\hline $\begin{array}{l}\text { Self-employed, landlord, } \\
\text { landowner }\end{array}$ & $(58) 54$ & $(6.44) 5.74$ \\
\hline Public and private official & $(200) 251$ & $(22.20) 26.70$ \\
\hline Professional & $(195) 269$ & $(21.64) 28.2$ \\
\hline Trader, large business owner & $(247) 109$ & $(27.41) 11.60$ \\
\hline Craftsman, small business owner & $(114) 36$ & $(12.65) 3.83$ \\
\hline Clerk, assistant, employee & $(60) 85$ & $(6.66) 9.04$ \\
\hline $\begin{array}{l}\text { Smallholder, agricultural } \\
\text { labourer, factory worker }\end{array}$ & $(24) 36$ & $(2.66) 3.83$ \\
\hline Pensioner, refugee & $(3) 9$ & $(0.33) 0.96$ \\
\hline Total (completed data sets) & $\mathbf{( 9 0 1 ) ~ 9 4 0}$ & $\mathbf{( 1 0 0 ) ~ 1 0 0 ~}$ \\
\hline
\end{tabular}

Karady, V. (2012): 127-129.

Tóth, Z. (1987): 67-87. 
In the course of the categorization, data from all completed fields were recorded. Where the father/guardian retired during the student's studies, we also categorized them according to their former occupation, leaving us with only two "retired" entries without further information. In the first category (self-employed, landlord, landowner), we included all data that clearly indicated the occupation. Among private and public officials, we have included all officials, whether they were employed at banks, mines, public administration or the Hungarian State Railway Company. Regardless of their occupation, we included doctors, teachers and those with a degree in law (judges, prosecutors, lawyers) as professionals. Teachers who also acted as school headmasters were added to this category, but also a doctor who worked as a chief medical officer. While the classification of the craftsman - small business owner - smallholder category was clear, in the trader - large business owner category we could not take into account the different financial statuses covered by the term "trader." Further research could determine the size of the business only on an individual basis (if data is available). The clerk - assistant - employee field includes all occupations performed without a higher education qualification, as an employee (including salesmen, for example, in addition to the named ones). We also classified the small number of data registered as smallholders in the category of smallholder - agricultural labourer.

The results obtained show practically the same ratios in some categories (in addition to the change in religious composition). There is a difference in the trader - large business owner and the craftsman - small entrepreneur - smallholder group. The decrease in the former is largely due to the decrease in the number of students whose fathers were Jewish large business owners and traders and the reorganization of the Budapest - countryside distribution discussed above. The decrease in the ratio of the craftsman - small entrepreneur - smallholder stratum can be explained primarily by the Great Depression and that families found it increasingly difficult to finance the studies of university student children.

There was a slight increase in the number of officials, large business owners and traders, and students with an intellectual family background, further reinforcing the process of these groups providing a new supply of doctors. This is mainly due to the fact that, in addition to the reproduction of the profession through generations, few people have been able to pay for the cost of training (tuition, housing in another city, travel, etc.).

\section{Issues of student enrolment before the Medical Faculty and University Council during the period studied}

Due to the characteristics of medical training, the number of students to be admitted was determined centrally at the time (and in later periods as well), taking into account the circumstances of the given faculty, mainly the number of places available for practical training. In the early 1930s, the Medical Faculty in Pécs requested 60 students to be admitted ${ }^{7}$. This was influenced, increasingly so from the 1930s, by other efforts, which we present with an overview of the cases and reports before the councils of the medical faculty and the university.

The first major controversy was sparked by an unexpected player, the medical faculty in Budapest. In January 1932, it turned to the rural medical faculties with a seemingly innocent inquiry about how the first-year enrolment numbers had been calculated based on numerus clausus in recent years, and whether there had been a deviation from the plans ${ }^{8}$. After these figures were sent out, a newspaper article informed not only the public but also the other

\footnotetext{
7 PTE EL VIII.105.a. ETE, OtK Kari ülési jegyzőkönyvek (Records of Faculty Council, hereinafter KT-jkv), 1929.6.21. agenda item \#10.; 1930.6.3. agenda item \#11.; 1931.6.8. agenda item \#15.

$8 \quad$ PTE EL VIII.105.a. ETE, OtK KT-jkv 1932.1.15. agenda item \#26.
} 
medical faculties that professor Balázs Kenyeres ${ }^{9}$ had prepared a memorandum, ${ }^{10}$ which was published by the newspaper Magyarság on 28 January $1932 .{ }^{11}$ According to the article, the compilation of the data series was started at the request of the Hungarian National Medical Association, as over-training was seen as the primary reason for the livelihood difficulties of doctors. Within this, as the exaggerated subtitle of the newspaper article shows, the main aim was to reduce the proportion of Jewish students. The exaggerations of the memorandum and the article caused a heated response in Pécs as well. The council of the medical faculty dealt with the matter on 29 January, the day after the article was published. ${ }^{12}$ According to professor Mihály Pekár, destructive tendencies can be observed in the article of the Magyarság newspaper, which published false data. For the first semester of the academic year 1931/1932, Pekár disclosed exact figures of Jewish students enrolled: Budapest (11.43\% of the total number of students), Pécs (22.29\%), Szeged (22.70\%), Debrecen (24.03\%). Regarding the proportion of graduated Jewish doctors, their ratio is the same at the three rural universities (Pécs, Szeged, Debrecen): they equally make up about $20 \%$ of the student body. He proposed a correction to be published in the newspaper and suggested that the Budapest medical faculty should be asked to send the memorandum to the medical faculty in Pécs. Professor Béla Entz added that this is another proof of the hostile behaviour of the Budapest medical faculty.

Surprisingly, the report was not completed until a few months after the outrage; it was sent "to the sister faculties and to all the factors which, without knowing the facts or deliberately misrepresenting them, attribute it to our Faculty that there is an overproduction of medical diplomas, and that in the absence of clear guidance, the law is interpreted in a different way or in a way that is not in line with its spirit, and thus the faculty has issued medical diplomas to those who were not eligible according the correct interpretation of the law."13 This may not have had much of an effect on subsequent events, as the letter of the Hungarian National Medical Association was presented at the same meeting, asking the Ministry of Religion and Public Education to keep the number of newly enrolled medical students under 300 nationwide. ${ }^{14}$

Even more visible to the public, from December 1933, several student associations at a number of universities in the country launched an enrolment strike. A general assembly was held in Pécs on 15 December 1933, at which it was announced that in protest they would not register for the second semester of the 1933/1934 academic year. The demands included the execution of numerus clausus and action against Jewish students in general. The university council discussed the events on 31 January, ${ }^{15}$ reporting that following an inter-university meeting held at the Ministry of Religion and Public Education on 4 January, measures had been taken to dissolve the Pécs committee that had organised the strike, which was acknowledged by the committee chairman János Kraszkó, a medical student. In January 1934, several organisations gradually withdrew from the initiative, and the small number of radical students "who were willing to go to

\footnotetext{
9 MoÉL 205.

10 Semmelweis Egyetem Központi Levéltára (Semmelweis University Central Archives). 1.a 58. Budapesti Királyi Magyar Pázmány Péter Tudományegyetem Orvostudományi Karának ülései (Budapesti Royal Hungarian Péter Pázmány University, Records of Medical Faculty) 1932.01.26., agenda item \#45.

11 The title reads: "The striking statement of the University of Budapest against medical over-training. They want to drastically reduce the number of students who can be admitted to medical schools. Six hundred and seventy doctors from the countryside moved to Budapest, of whom six hundred and sixty-three are Jews." Magyarság 1932.01.28. 8.

12 PTE EL VIII.105.a. ETE, OtK KT-jkv 1932.1.29. agenda item \#16.

13 PTE EL VIII.105.a. ETE, OtK KT-jkv 1932.6.7. agenda item \#29.

14 PTE EL VIII.105.a. ETE, OtK KT-jkv 1932.6.7. agenda item \#31.

15 PTE EL VIII.1.a. ETE, A Pécsi Egyetem Tanácsának ülésjegyzőkönyvei (Records of University Council, hereinafter ET-jkv) 1934.01.31. agenda item \#14.
} 
extreme measures and thus endangered the great interests of the state"16 failed to achieve their goal, especially after the university extended the enrolment period. ${ }^{17}$

In March 1937, the University Council, ${ }^{18}$ then in May 1937 the Medical Faculty Council ${ }^{19}$ discussed a petition from several youth associations, requesting a guarantee that no more Jewish students would be admitted to the university until their number dropped below 5.1\%, that the foreign diplomas of Jewish students would not be neutralised, and that baptized Jews should also be treated as Jews. The response of the university council was twofold: the council asked faculties to adhere to the numerus clausus numbers that at that point no longer existed by law, to not neutralise foreign diplomas, and to consider the request that baptized Jews be considered Jews. At the same time, the admission limit of $5.1 \%$ was rejected. The dean of the Faculty of Humanities, József Halasy-Nagy, made important additional points regarding his faculty: "[...] no one can name a single youth who has been deprived of the opportunity to study at this faculty [...] under the existing rules, the presence of Jewish students, the tuition fees they pay, enables 15 Christian students to benefit from a balf-tuition discount." He also notes that as long as a large proportion of Christian students do not exercise their right to enrol in Pécs because they have been enrolled elsewhere, all admitted Jewish students will enrol. ${ }^{20}$ Contrary to the practice of the 1920 s, here we can already see stances contrary to the raw interests of the faculty and the university (i.e., maximizing the number of students). In addition, several processes have led to a decrease in the number of students, with Hungary being the last in Europe in terms of the proportion of students participating in higher education. It was under these circumstances that the number of students were administratively limited, due the high number of unemployed graduates. The birth deficit of the war period also reached the higher education at that time, and the secondary education requirements for admission to higher education gradually decreased. ${ }^{21}$ In terms of the enrolment of Jewish students, the above cited anti-Jew laws restricted their access to universities, with the Second Jewish Law of 1939, Art. IV. limiting their proportion to 6\% (relative to all students in the faculty).

\section{Careers of students graduated from the Pécs medical faculty}

In addition to outlining the statistical data, we would like to introduce the doctors graduating in Pécs by presenting some of their careers. Of course, we need to keep in mind that we have more or at all considerable resources about the more successful careers. Our sources were mainly (in addition to university records) data repositories, contact lists, obituaries, and commendations, which were also quite incidental and by no means representative. First we present students from a county, the second group shows students starting their education in universities abroad. The third group consists of female students, while the last showcases multigenerational medical families.

1.

Based on our previous research, ${ }^{22}$ we first present doctors that can be connected to a single area, Somogy County. Following his graduation in 1937, Ferenc Wirth, a doctor of internal medicine, returned to Somogy County and had a significant career. He worked at the Kaposvár Hospital

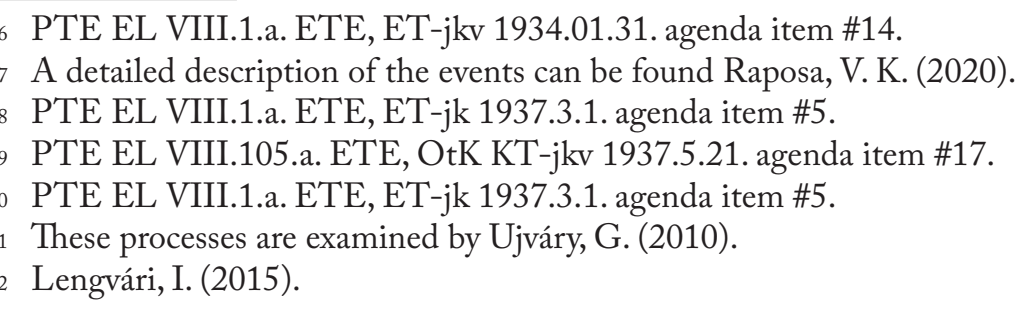


from 1951, and was the chief physician of the 1st Department of Internal Medicine, and from 1952 to 1954 he also served as medical director of the Hospital. ${ }^{23}$

György Révész, born in Kaposvár, received his medical degree in 1940, worked in several institutions in Budapest until 1951, then became a professional military doctor; he was the head of the Otorhinolaryngology Department of the Central Military Hospital, and from 1955 of the Officers' Hospital. From 1967 he was a professor and director of the Semmelweis University's Otorhinolaryngology Clinic, and from 1975 he was the director of the National Institute of Otorhinolaryngology. ${ }^{24}$

A member of a family of doctors, Sándor Barla Szabó came to the faculty from the secondary school in Csurgó, and after graduating he served in the military during the World War. He specialized in rheumatology, and from 1954 he worked in Harkány as a chief physician and then as a director. The reconstruction and expansion of the hospital is associated with his name, and he also carried out significant scientific work. ${ }^{25}$

A pair of brothers from Somogy also obtained a medical degree here: Gyula Takátsy graduated from the faculty in 1938 and was an intern at the Institute of Anatomy and then the Institute of Public Health, then he worked at the National Institute of Public Health from 1945 until his retirement. He carried out important research on typhoid fever and then influenza. ${ }^{26}$ His older brother by two years, Tibor Takátsy, was born in 1912, and after graduating, he worked at the Gynaecology Clinic in Pécs, then he was a departmental chief physician in Tatabánya from 1946 and then from 1953 in Szombathely. He also carried out significant work as a painter, medal designer and textbook writer. ${ }^{27}$

We have reports about Gyula Ficzkó, a medical student experimenting with "avant-garde short stories and novel" ${ }^{28}$ from his student years, and Sándor Tatay also mentioned him in his novel. ${ }^{29}$ He left behind his literary companions such as Sándor Weöres, Nándor Várkonyi, Sándor Tatay and other literary scholars in 1942, when he graduated and became a family doctor in Letenye. He actively participated in politics, and in 1945 the local press already reported about his arrest, internment, and trial before the People's Court. ${ }^{30}$

We have much less or only a single piece of data for some students. In the case of some recent graduates, the minutes of the council meetings of the medical faculty report that they started working at a clinic as an unpaid intern. Thus, at the Paediatric Clinic, Ernő Mózsa ${ }^{31}$ and Lehel Szíjártó, ${ }^{32}$ Jenő Pleszky ${ }^{33}$ at the Obstetrics, and Lenke Sára ${ }^{34}$ at the Internal Medicine Clinic. Zoltán Práger, who was a doctor in Kaposvár after graduating in 1936, was a victim of the Holocaust. ${ }^{35}$ Imre Práger (unrelated to Zoltán) finished six semesters abroad (in Prague) which he credited towards his studies in Pécs, with the support of the faculty. ${ }^{36} \mathrm{He}$ graduated in

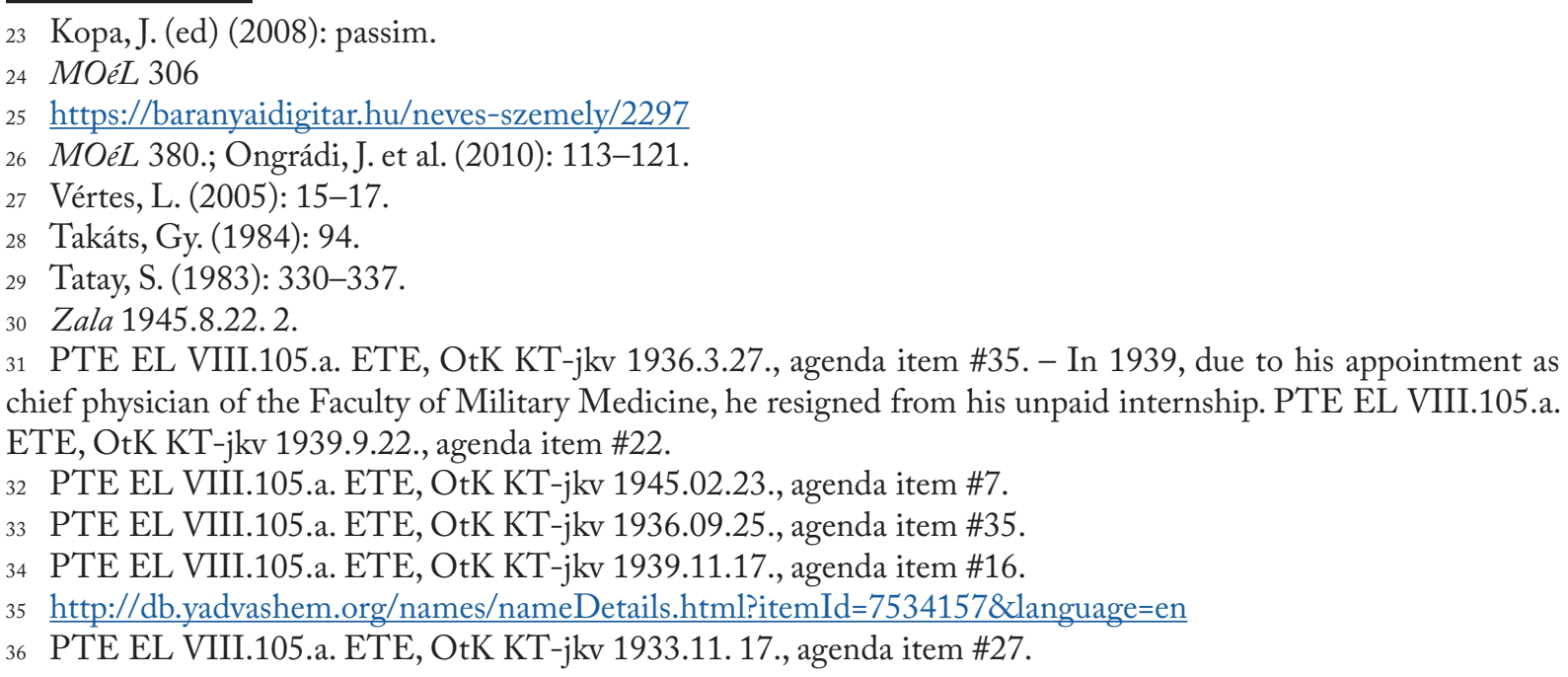


1936 and the only further data we have of him is about is death in $1987 .{ }^{37}$ There are some who pursued a career abroad, such as Kálmán Dezső Merényi, who was born in 1920 and graduated in 1944, and worked as a pathologist in the United States, in the state of North Carolina, according to a roster from $1982 .{ }^{38}$

\section{2.}

In the analysis of the higher education conditions of the period and in the case of contemporary criticisms of the university, it is often brought up that it was possible to circumvent the restrictive measures against Jews by naturalising studies started abroad. In the decade and a half we examined, we found 24 graduates who finished their studies started abroad at the medical faculty in Pécs. In most cases, after a shorter or longer stay abroad, students spent at least four but usually more semesters in Pécs before graduating. 13 of the 24 cases are Jewish students who had credited semesters completed at universities in the Czech Republic, Austria, Italy and Germany towards their studies. Such an example is Margit Rares from Sopron, who successfully applied for admission to the University of Tübingen in the autumn of 1924, after graduating from secondary school, noting in her biography that she could not study in Hungary as a Jew because of the numerus clausus law. ${ }^{39}$ In a letter written about Pécs in February 1926, she asked the University of Tübingen to certify some of her courses, otherwise her two semesters would not be recognised here. ${ }^{40}$ After some breaks in her studies, she graduated in 1935, and in 1940 she worked as a dentist in Sopron. ${ }^{41}$ We have no knowledge of his future fate.

\section{3.}

Several female medical graduates from the period found jobs not only in the field of healing but also in research. ${ }^{42}$ Klára Kovács (1912-1982) obtained her medical degree at the medical faculty in Pécs in 1936, and in 1941 she became a paediatrician. She was deported to Germany in 1944, between 1945 and 1948 she worked as a paediatrician for the National Aid, then she became a family and occupational physician. From 1951 she was an associate professor at the Institute for the Further Training of Physicians, and in 1968 she also obtained the title of candidate. Her career, which began before the war, was interrupted by deportation, and after the war, her career unfolded similar to that of her male colleagues, including a career in research. ${ }^{43}$ She was not the only one to suffer such a break in her career. Lidia Keppich, who graduated in 1927, became an ophthalmologist, and she and her husband (Emil Oláh), who chose the same specialisation, were deported from Gyula, where she completed her secondary education ${ }^{44}$ and where she returned to after graduating from university. After being doctors at the Kitlitzleben

\footnotetext{
37 http://www.geni.com/people/dr-Pr\%C3\%A1ger-Imre/6000000002421639269

38 Roster of registered physicians in the State of North Carolina. March 1, 1982. Issued by Board of Medical Examiners of the State of North Carolina. Raleigh (1982):191.https://archive.org/stream/rosterofregister1982nort\#page/190/ mode/2up/search/merenyi

39 Universitätsarchiv Tübingen. Signatur: 258/14611. - I wish to express my gratitude to Prof. Dr. Márta Fata for releasing the documents to me and to Adrienn Wéber for translation from German.

40 Universitätsarchiv Tübingen. Signatur: 258/14611.

41 Az Országos Orvosi Kamara bivatalos nérjegyzéke. III. évfolyam. Budapest, (1940): 178.

42 Lengvári, I. (2008).

43 MOéL 217.

44 https://web.archive.org/web/20091012105159/http://www.kjkg.sulinet.hu/honlap/evkonyv_adattar_szazev. $\underline{\mathrm{htm}}$
} 
camp (their patients even included an SS officer), ${ }^{45}$ they both returned to Gyula. Her husband worked as a chief physician in Gyula until $1964,{ }^{46}$ we have no further data on his wife.

Erzsébet Kálmán (Mrs. Viktor Faber, 1916-1965) was born in Pécs and obtained her medical degree in 1940 at the Faculty of Medicine in Pécs. Between 1940 and 1944 she worked as a radiologist at the State Hospital in Kolozsvár, then between 1944 and 1947 she was a paediatrician. Between 1947 and 1948 she worked at the Paediatric Clinic in Pécs, then in 1949-1950 she was a paediatrician at the State Hospital. From 1951, she worked in the field of radiation biology and X-ray diagnostics, from 1956 she was the head of the scientific department at the National F. Joliot-Curie Institute of Radiobiology, and in 1961 she received the title of candidate of medicine. ${ }^{47}$

Reneé Oberson (Mrs. László Fonó, 1908-1975) passed the paediatrician (then the radiologist) qualification exam after graduating in 1938. Between 1938 and 1940, she worked at the State Children's Shelter and then at other hospitals. She worked in Budapest at the Second Paediatric Clinic, where from 1942 she was an assistant professor then senior lecturer, from 1956 she became a candidate and associate professor, finally she obtained a doctorate in medicine in 1972. She was a renowned paediatric cardiologist in Europe, one of the first to perform heart surgeries on children in Hungary. ${ }^{48}$

Careers so far show the common perception that female doctors have worked primarily as paediatricians, radiologists and ophthalmologists. In addition, dentistry has joined these specialisations. Júlia Szanathy returned to Gödöllő to work as a dentist after her internship, continued to work there until 1982, and died in 2003 at the age of $96 .{ }^{49}$ She also comes from an important family in terms of schooling strategy: her sister, Aniella, was the first Hungarian female lawyer. ${ }^{50}$ She recalls that in the 1930s, 4 out of 18 recruited interns were women. She also continued to work as after having a family. The fact that he bought Adél Brüll's (Endre Ady's Léda) salon furniture set for 800 pengós in the late 1930s is a good indication of a secure livelihood. ${ }^{51}$

To showcase the scientific advancement of local women, we present the career of Margit Mittag, who became an unpaid intern at the Institute of Anatomy in 1926, ${ }^{52}$ an assistant professor at the Clinic of Internal Medicine in 1946, ${ }^{53}$ at which time she is mentioned in the sources under her married name, as the wife of the outstanding scientist Szilárd Donhoffer. They published several joint articles, then she carried out independent research dealing with clinical dietetics; she also wrote a popular series of books on the subject. Their two daughters also chose a medical career. ${ }^{54}$

\section{4.}

Carmen Camillo (born in 1922), the daughter of a professor at the university in Pécs, Reuter Camillo, ${ }^{55}$ followed in his father's footsteps and became a neurologist. After graduating in 1945, she worked as an unpaid intern at the Neurological Clinic, from which post she resigned in

45 Excerpts from the conversation of László Kemény, György Márai and Gyula Erdmann (1986) https://web. archive.org/web/20070705022236/http://www.bekes-archiv.hu/forras/jewish/convers.html

46 https://web.archive.org/web/20090404043004/http://gyulai info.extra.hu/elet/adattar/gyki.htm

47 MOéL 201.

48 MOéL 101-102.

49 Gödöllöi Szolgálat X:41, 2001.11.8. 10; XIII:1, 2004.1.15.7.

50 Lengvári, I. (2021b).

51 G. Merva, M. (2002).

52 PTE EL VIII.105.b. ETE OtK Department of Anatomy 465/1925-26.

PTE EL VIII.105.b. ETE OtK Department of Anatomy 354/1945-46.

Szelényi, Z. (2002).

PEA I: 163. 
October 1947. ${ }^{56}$ After working in Budapest for a while, she was the chief neurologist of the sanatorium in Sopron until her retirement. ${ }^{57}$

László, the son of another renowned professor in Pécs, the radiologist László Rhorer, obtained his medical degree in 1935, and then went on to work with László Verebélÿ at the Department of Surgery of the Pázmány Péter University in Budapest. He studied under the name of László Rhorer Küllői at several Western European clinics, then he worked as a frontline doctor during World War II. He was an assistant professor at the $2^{\text {nd }}$ Clinic of Surgery in Budapest from 1947, then from 1957 to 1977 he was the chief physician at the $1^{\text {st }}$ Surgery of the Hungarian State Railways Hospital in Budapest. He was recognised by posterity as one of the best physicians in all disciplines, working with outstanding surgical and scientific excellence. ${ }^{58}$

Lajos (1908-1984) and Dezső (1912-1997) Kollár, the children of István Kollár who worked in Pécs as a dentist, also followed their father's profession. ${ }^{59}$ Lajos graduated in 1932 and began working at the university's Clinic of Surgery. ${ }^{60} \mathrm{He}$ played an important role in setting up and equipping the Dental Clinic. ${ }^{61}$ He was dismissed in 1946, and until his death he was the chief dentist of the Hungarian State Railways Hospital. ${ }^{62}$ After his graduation in 1937, Dezső worked at the Clinic of Surgery, then between 1947 and 1982 at the Paediatric Clinic as the head of the Department of Otorhinolaryngology. He was a renowned textbook author who performed about 40,000 surgeries during his career. ${ }^{63}$

These are only some examples - it is essential to examine further individual careers of graduates to understand the social mobility of the graduates of the Medical Faculty.

\section{Sourcebooks}

MOéL (2004), Kapronczay, Károly: Magyar Orvoséletrajzi Lexikon. Budapest PEA I. (2015), Lengvári, István (Ed.): Pécsi Egyetemi Almanach I. 1367-1950. Pécs

PEA II. (2017), Polyák Petra (Ed.): Pécsi Egyetemi Almanach II. 1951-1999. Pécs

\section{References}

Dezső, K. (2019), A pécsi Stomatológia Intézet műszerei.https://tgyoblog.wordpress.com/2019/04/04/ a-pecsi-stomatologia-intezet-muszerei/

G. Merva, M. (2002), A gödöllői Léda villa titkai. Holmi 14:8. 1037-1043.

Huszár, Gy. (1984), A vizsgázott fogászok munkássága az 1910-es években, in: Antall József (Ed.): Orvostörténeti közlemények 105-106. Budapest, 131-137.

Karady, V. (2012), The restructuring of the academic market place in Hungary. In: Karady, Victor - Nagy, Peter Tibor (Ed.): The numerus clausus in Hungary. Studies on the First Anti-Jewish Law and Academic Anti-Semitism in Modern Central Europe. Budapest, 2012. 112-135.

Karsai, L. (2005), A magyarországi zsidótörvények és -rendeletek, 1920-1944. In: Molnár Judit (Ed.): A holokauszt Magyarországon európai perspektivában. Budapest, 140-163.

Kopa, J. (Ed.), A Kaposi Mór Oktató Kórház 160 éve. Kaposvár 2008.

Kulka, F. (1987), In Memoriam Dr. Küllői Rohrer László. Orvosi Hetilap 128: 52.2753.

\footnotetext{
PTE EL VIII.105.a. ETE, OtK KT-jkv 1947.10.24., agenda item \#17.

Kisalföld, 1963. június 21. 3.; Kisalföld, 2018. december 18.17.

Kulka, F. (1987).

The multigenerational dentist families were already noticed by Huszár, Gy. (1984): 35.

PTE EL VIII.105.a. ETE, OtK KT-jkv 1938.3.18. agenda item \#27.; 1940.01.19. agenda item \#8.

Dezső, K. (2019).

http://virtualis.sk-szeged.hu/kiallitas/orvoslas-ekf/fogaszat/kollar.html

PEA II:65.
} 
Lengvári, I. (2008), A pécsi Magyar Királyi Erzsébet Tudományegyetem Orvostudományi Karának női hallgatói (1919-1945). In: Parasztok és polgárok. Tanulmányok Tóth Zoltán 65. születésnapjára. Czoch, Gábor - Horváth, Gergely Krisztián - Pozsgai, Péter (Ed.) Budapest, 2008. 402-403.

Lengvári, I. (2015), Somogyi hallgatók a pécsi Magyar Királyi Erzsébet Tudományegyetem Orvostudományi Karán, 1919-1945. In: Mayer, László - Tilcsik, György (Ed.): Szorosadtól Rijekáig. Tanulmányok Bösze Sándor emlékére. Budapest, 227-228.

Lengvári, I. (2021a), The Social Composition of Medical Students at the Erzsébet University in the 1920s. In: Kaposi, Zoltán - Rab, Virág: Studies on Economic and Social History from Southern Transdanubia I. Pécs, 72-79.

Lengvári, I. (2021b), Szanathy Aniella, az első jogi doktornő Magyarországon. In: Lengvári, István (Ed.): Az Év Levéltára 2020. A 2021. április 13-án tartott konferencia elóadásai. Pécs, 53-65.

Ongrádi, J. et al. (2010), Takátsy Gyula életművéről. Harminc éve halt meg a virológus. Egészségtudomány 65: 4. 113-121.

Raposa, V. K. (2020), A pécsi bajtársiak antiszemita beiratkozási sztrájkja az 1933/34-es tanévben. Per Aspera Ad Astra 7:1.71-99.

Szelényi, Z. (2002), Három negyedszázad Donhoffer professzor szakmai életében. A tudós diagnoszta, a kórélettan pécsi megalapítója, és a bölcs, önzetlen tanácsadó. Orvoskari Hírmondó 2002:10. 7-11.

Takáts, Gy. (1984), Helyét keresó nemzedék. Költók levelei 1934-1949. Budapest

Tatay, S. (1983), Lődörgések kora. In: Tatay, Sándor: Hét szúk évtized. (Tatay Sándor mürvei.) Budapest 145-383.

Tóth, Z. (1987), Társadalmi státus és foglalkozás az osztrák és magyar társadalomstatisztikában. Statisztikai Szemle 65.67-87.

Ujváry, G. (2010), Az egyetemi felvételi rendszer változásai a 20. században. In: (Ed.): A felsóoktatási felvétel szabályozásai a két világháború közötti Magyarországon. Budapest, 9-23.

Vértes, L. (2005), Takátsy Tibor szülész-nőgyógyászról. Orvoskari Hírmondó 2005:9. 15-17. 